\title{
Devolution from the Centre to the Periphery: An Overview of Ottoman Provincial Administration
}

\author{
I. Metin Kunt
}

Wars change societies; long wars change them even more profoundly. During the long career of the dynastic empire (c. 1300 to 1922) Ottoman provincial administration was transformed in significant ways more than once. Perhaps the most significant changes - at least until the Europeanising reforms of the nineteenth century-occurred at the turn of the seventeenth century, after a period of about thirty years of warfare and internal ferment. Successfully concluding the conquest of Azerbaijan (1578-1590) from the Safavis torn by throne struggles, the Ottoman government turned its military might against the Habsburgs in central Europe in 1591, perhaps in accordance with the political wisdom of the age that 'soldiers should be on campaign'. Victory in the East whetted the Ottoman appetite for conquest in the northwest, but the traditional Ottoman military organisation was found wanting against Austrian armies, with far-reaching consequences. Provincial cavalry supported by revenue grants was neither equipped nor trained sufficiently for changing European warfare, and when some of them were dismissed from active service, they triggered internal turmoil. Meanwhile, having settled their own internal problems, Safavi armies now under Shah Abbas regained territories recently ceded to the Ottomans. A stand-still peace was signed with Austria in 16o6, and rebels in Anatolia and Syria were brought to heel in 16o8, though the eastern front remained active until 1639. After more than thirty years of almost continuous action, sometimes simultaneously on three fronts, the Ottoman conception of government evolved to suit changing times. ${ }^{1}$

1 I have written about this change in The Sultan's Servants: the Transformation of Ottoman Provincial Government, 1550-1650 (New York, 1983). Baki Tezcan considered the shift so momentous that his recent book is called The Second Ottoman Empire: Political and Social Transformation in the Early Modern World (Cambridge, UK, 2010), partly also as a reference to the short, unhappy reign of Osman II (1618-1622), the second after the eponymous founder of the dynasty (the third and last Osman reigned in 1754-1757). The nature of the change used to be considered the beginning of the long decline of the Ottoman Empire, but Ottomanists of the last generation have abandoned this misleading conception. For the Austrian War from the Ottoman perspective see Caroline Finkel, The Administration of Warfare: the Ottoman Military Campaigns in Hungary, 1593-1606 (Vienna, 1988). For the internal situation see Karen Barkey, 
Having begun as a minuscule frontier society, the Ottoman realm expanded through raiding as well as by concerted military action. As territories came under Ottoman control they were left to the care of military commanders, ghâzi frontier lords, sometimes the same captains who in fact had led the conquest. The realm was divided into districts termed 'banners' (Ottoman Turkish sancak, pronounced 'sanjak'), and the governor was the 'banner commander' (sancakbeyi). In some fifteenth- and sixteenth-century district regulations (kânûnnâme) the governor is in fact referred to as the 'cavalry banner commander' (atlı sancakbeyi), leaving no doubt as to his essentially military function. ${ }^{2}$ Narrative accounts, too, sometimes refer to 'banner' as a group of cavalrymen, a battalion or regiment, rather than as a geographical district. The banner commander was, of course, responsible for the safety and order of his whole district, and the collection of revenues allocated to him in his district allowed him a measure of additional authority over the townsmen and peasants specifically within his revenue grant. He collected annual land rent, taxes on agricultural and artisanal production, commercial duties and fines for various types of transgressions. He was, then, an administrator of his district, and more closely of those parts of his district left in his personal care, but what defined him as an Ottoman official was the fact that he was a military administrator, the commander of the provincial cavalry who led his regiment to battle when ordered and presented his troops for muster when the army gathered. The banner then marched in formation with other banners of the same province, in a brigade or division, but nearer the front it might be given discrete tasks for reconnaissance, forward, or rear guard duty.

Early on, banner commanders were frontier lords, companions of the first few Ottoman rulers and similar if not quite equal to them in political and military stature, leaders of their own household men as well as of the independent

Bandits and Bureaucrats: Ottoman Route to State Centralization (Ithaca, 1994). On Ottoman warfare in general see Rhoads Murphey, Ottoman Warfare, 1500-1700 (London, 2002).

2 For books of regulations, including district regulations, see Halil İnalcık, 'Kânûnnâme', Encyclopedia of Islam, C.E. Bosworth, E. van Donzel, B. Lewis and Ch. Pellat, eds., Vol. 4 (Leiden, 1960; 2nd edition Leiden, 1978), 558-566, and Heath W. Lowry, 'The Ottoman Liva [sancak] Kanunnames Contained in the Defter-i Hakani [district census registers]', Osmanlı Araştırmaları Dergisi [Journal of Ottoman Studies] 2 (1981), 43-74. For references to 'cavalry banner commander' see Ö.L. Barkan, XV. Ve XVI. Asırlarda Osmanlı İmparatorluğunda Zirâi Ekonominin Hukuki ve Mâli Esasları, I. Kanunlar [The Legal and Fiscal Bases of Agricultural Economy in the Ottoman Empire in the 15th and 16th Centuries, I: Regulations] (Istanbul 1943), 5, 27, 70, 180, 268, 396 . 
revenue-holding cavalrymen in their march-turned-district. Troop captains who served within the households of such lords as well as others who rose through the ranks of independent cavalrymen and minor district officers could hope to become banner commanders themselves someday. As the state evolved as a dynastic empire and expanded, the frontiers and the frontier lords became more distant from the centre and their political clout lessened, at least in relative terms. The sultan's own servitors, trained at the palace and then joining provincial administration, tended to have the fast-track of promotion, especially from the middle of the fifteenth century on. After serving no longer than two or three years in a certain district, the banner commander would be transferred elsewhere, usually in the same province; if he was deemed successful with each successive appointment he would be given a relatively more important command. Of the three hundred or so banner commanders in the sixteenth century a few rose to the rank of 'commander-of-commanders' (beylerbeyi), that is, governor-general of one of the twenty or so provinces in the realm, most of whom had been trained in the sultan's household. The top of the Ottoman cursus honorum was the imperial council which sat at the palace where there was room for a number of vezirs, seven in the sixteenth century, promoted from among the beylerbeyi.

An Ottoman official, even more than a Roman senator, was a man of the sword, a military commander first and an administrator second. This was so not only because he left the finer points of fiscal matters to the men of the pen in his own entourage but especially because provincial administration had a second, parallel but separate arm, made up of men of learning, the kâdı judge-magistrates. These two careers were known in Ottoman terminology in a rhyming duality, from the Arabic plurals of the men of the sword, the ümerâ, and the men of learning, the ulemâ. The men of the pen, the küttab scribes, were somewhere between the two and not considered to constitute a separate career, at least not until after the seventeenth-century transformation. A scribe might be trained in a household like the ümerâ, or educated at a medrese college like the ulemâ, but in terms of career advancement his hope would be to achieve a district command after serving in the imperial palace or in the household of a governor.

In the provinces, while the banner commander kept the peace and went on campaign whenever required, the kâdı judge-magistrate stayed put for the duration of his appointment at a particular post, equally as short as that of a banner commander. There were no local roots for Ottoman administrators. The kâdı was a judge, but he was also assigned state business. Imperial decrees were very often addressed to both the banner commander and the judgemagistrate of a district, who were to cooperate and coordinate their efforts 
to fulfill the tasks given them. ${ }^{3}$ The ulemâ career too had its own ladder from lesser appointments to larger cities, and their ladder too ended in the imperial council, as the two most senior judge-magistrates sat alongside the ümerâ vezirs at meetings led by the grand vezir. Since one of the main features of the seventeenth-century transformation is the relative civilianisation of Ottoman polity, we shall return to the enhancement of the position of judge-magistrates as well as the emancipation of the scribal career.

\section{Princes as Banner Commanders}

The Ottoman dynastic empire brought relatively little of its distant Inner Asian heritage to the territories it conquered, whether from the infidels or from fellow Muslims. These were agrarian lands; the original transhumant character of the minuscule Ottoman frontier enterprise was soon abandoned in favour of a proper sedentary empire. Tribal groups, Turkish or otherwise, were treated with suspicion, subdued, forced to migrate, broken up, and ultimately reduced to subject status. A few traces of Inner Asia remained, however, such as fifteenth-century writings in the Uygur script and even some runes. In addition to the Viking runic grafitti in Byzantine St Sophia there are Ottoman writings that hark back to the Göktürk runes in the Altai inscriptions and also Hungarian texts, themselves bearing traces of their Inner Asian roots. But it is especially in terms of the dynasty itself that Asia appears. Even when Ottoman rulers, at first styled simply beys and ghâzis like other commanders in the polity, were elevated above the others and adopted the Islamic 'sultan', the Persian 'pâdishâh' and even the Roman 'çâsâr' (caesar) — briefly, after the conquest of Constantinople - they always, up to the very end of empire, kept the Turkic 'khan' among their titles. ${ }^{4}$ The Inner Asian concept of dynastic rule was also reflected in the system of succession, though with modifications. When a ruling dynasty was established by a charismatic, eponymous leader, whether a simple chieftain or a world-conqueror, all male members of his family would participate in the rule. Succession depended not on primogeniture but on acclamation of any brother or son or cousin or nephew, either explicitly by

3 For the administrative and political role of a provincial kâdı in addition to his judicial function in the sixteenth century see Leslie Peirce, Morality Tales: Law and Gender in the Ottoman Court of Aintab (New York, 2003). As we shall see, as the kâdis role was elevated in the seventeenth century so has the literature on provincial courts increased in recent decades.

4 Halil İnalcık, 'Power Relationships Between Russia, the Crimea and the Ottoman Empire as Reflected in Titulature', in C. Lemercier-Quelquejay, G. Veinstein, and S.E. Wimbusch eds., Turco-Tatar Past, Soviet Present: Studies Presented to Alexandre Bennigsen (Paris, 1986), $175^{-211 .}$ 
a gathering of all the leaders in the polity or implicitly by their acquiescence. This Inner Asian way might have appeared not so much as a system but as a chaotic and irrational process to sedentary societies because it often caused wide-scale throne struggles and even civil war. It did, however, have the advantage of ending up with the most capable leader, the one with political nous as well as military prowess. ${ }^{5}$ The implication of this system of succession is that all male members of the dynastic clan had an appanage during the lifetime of the ruling khan.

In the Ottoman case, probably not deliberately but as a result of ad hoc responses to historical situations, the ruling family was able to keep succession from father to one of his sons, a situation Cemal Kafadar termed monogeniture. ${ }^{6}$ The son who won, either through political acumen or military prowess, then killed his brothers and their sons; there were no more nephews and cousins. Nevertheless, as in the Inner Asian tradition, all the sons of the ruler were eligible for the throne and as such during the lifetime of the father they all were assigned banner commands when they came of age to prepare them for the struggle against their brothers and eventual accession as ruler if they won. ${ }^{7}$ To prepare the child-prince for the inevitable showdown and possible reign he was assigned a statesman as tutor. He was also given — loaned, might be a better term-a startup household chosen for him from among the personnel of the imperial palace. Similar to all ümerâ households but unlike the imperial palace, the prince's retinue did not include any musket-bearing janissary infantry but only cavalry troops. Unlike in the steppe environment, an Ottoman prince never ruled in his own name; his status of banner commander was relatively low, since there were many ümerâ of superior pasha (for governors-general) and vezir rank. ${ }^{8}$ It was a matter of historical circumstance how many princes

5 Joseph Fletcher borrowed a term from the Gaelic tradition, tanistry, to explain Inner Asian tradition, 'Turco-Mongolian Monarchic Traditions in the Ottoman Empire', Harvard Ukranian Studies 3 (1979), 236-251; Halil İnalcık, 'The Ottoman Succession and its Relation to the Turkish concept of sovereignty', Halil İnalcık ed., The Middle East and the Balkans under the Ottoman Empire: Essays on Economy and Society (Bloomington, 1993) (originally in Turkish, 1959), 37-69.

6 Cemal Kafadar, Between Two Worlds: the Construction of the Ottoman State (Berkeley, 1996).

7 For dynastic reproduction see Leslie P. Peirce, The Imperial Harem: Women and Sovereignty in the Ottoman Empire (Oxford, 1993).

8 The most comprehensive monograph on Ottoman princes is Haldun Eroğlu, Osmanlı Devletinde Şehzadelik Kurumu (Ankara, 2004) [The Institution Princeship in the Ottoman State]; also see Feridun Emecen, XVI. Yüzyılda Manisa Sancağı (Istanbul, 1989) [The sancak of Manisa in the Sixteenth Century], important because Manisa had almost become the designated seat of the elder son at the time. 
there might be biding their time in the provinces at any given moment. How many sons naturally survived to become of age and outlived the father, how long the father lived, how long he reigned: these were all factors in the situation. In the first decade of the sixteenth century five sons of the reigning sultan, Bayezid II, were banner commanders. When Bayezid died in 1512 at age sixty-five after a reign of thirty-one years not only his middle-aged sons but also his grandsons were banner commanders. Furthermore, daughters of the princes were married to some banner commanders; the prince's sons and his sons-in-law governed districts adjacent to the prince's own banner district. By 1512, the sons of Bayezid not only were themselves in charge of a relatively modest banner, but together with their sons and sons-in-law each prince controlled a sizeable region. In this exceptional situation the eventual struggle for Bayezid's throne was therefore especially fierce, until Selim I emerged victorious and eliminated all the others involved.

A prince as banner commander was an anomaly because of the dynastic implications, especially since his military activities were limited to the hunt and to hunting bandits for he was not to take part in imperial campaigns much less lead campaigns of his own. Nevertheless, in terms of provincial administration his banner functioned as any other. There were, of course, independent $k a ̂ d \iota$ magistrates and the scribes in his own entourage who ran the day-to-day affairs. Revenues assigned to the prince were much higher than those allowed regular banner commanders, and therefore he had greater direct authority over a larger number of townsmen and peasants included in his own domain. He might have left his father's home at age ten or fifteen and then waited in the same or perhaps in several different districts for the next twenty or thirty years, not allowed back in the capital and not allowed to be an active participant in the political processes of the empire. At any rate, at about the same time that greater changes were wrought in Ottoman provinces, not related to these changes but once again due to the historical circumstances of the age of fathers and of sons, the practice of sending princes out to banners was given up. ${ }^{9}$ After Prince Mehmet went out to Manisa in 1582 and returned as Sultan Mehmet III in 1595 there was never another princely governor in the realm.

9 On the last prince to go out of the palace and the capital in 1582 to Manisa, Metin Kunt, 'A Prince Goes Forth (Perchance to Return)', in K. Barbir and B. Tezcan, eds., Identity and Identity Formation in the Ottoman World (Madison, 2008), 63-71. When Mehmet III died at age thirty-seven in 1603 his sons had not been of age yet to be sent out of the palace. The following few reigns also saw sultans dead at an early age, with children ascending the throne without provincial experience. 


\section{New Conditions, New Arrangements}

Already before the long wars at the end of the century the size of the imperial palace troops had increased considerably, partly by force of events, in the reign of Selim II (1566-1574) and partly by the deliberate policy of his son and successor Murat III (r. 1574-1595). ${ }^{10}$ Sultan Murat reversed the policy of his grandfather Sultan Süleyman, continued by Selim II, of allowing the emergence of a state bureaucracy, a machine to run the affairs of state routinely; he reasserted the supremacy of the sultan and his palace. In a sense, the Ottoman sultan was similar to the officers and officials of the realm. Like them he had revenues assigned to him and he had to maintain his own household out of these revenues. The imperial palace was, however, not only much bigger than other households, perhaps ten times the size of the grand vezir's three or four thousand men, it also had two distinctions: troops with firearms and the right to recruit from the Christian population of the realm. While the provincial cavalry brigades under the banner commanders practised traditional skills, imperial household troops, especially the janissary musket-bearing infantry, were able to train en masse. Military innovations, whether techniques or technology, were developed and applied in the janissary companies and in the armaments and cannon corps. At the end of the sixteenth century political and military considerations coincided: the provincial cavalry was downgraded and the imperial household troops increased. The sultan's expenditure on household personnel grew in turn.

The fiscal consequence of this decision was an effort to augment the sultan's revenues at the expense of lower-level revenue grants in the provinces. However, this shift could not simply be a matter of internal redistribution of resources-not that it was simple in any case. The Ottoman agrarian system produced tax revenues partly in kind, the tithe produce to be consumed or marketed by the holder of the right to collect. In smaller, lower-level revenue grants the proportion of revenues in kind was higher; in larger revenue holdings there were considerable commercial and trade taxes payable in cash. For central revenues to increase there was need also for a greater degree of monetisation in the realm, for greater amounts of silver for the coinage, and a greater degree of circulation. Otherwise if he only appropriated lower-level revenue grants, the sultan would end up with stores of produce in many small holdings, which

10 Metin Kunt, 'Turks in the Ottoman Imperial Palace', J. Duindam, T. Artan, M. Kunt, eds., Royal Courts in Dynastic States and Empires: A Global Perspective (Leiden, 2011), 289-312. 
would be of little use in paying his soldiers' wages in Istanbul. World-wide changes in the sixteenth century as a result of the expansion of Europe, more specifically Portuguese and Spanish activities across the oceans, as well as new directions of the Ottomans' own expansion provided the increased supply of silver, at least some of it, for Ottoman purposes.

In the Mediterranean the Ottomans exported more than they imported; there was a healthy balance of payments surplus. Not that the Ottomans were bullionists avant la lettre. Ottoman provisionism tried to limit exports and even banned them in certain cases. Nevertheless, some of the silver the Spanish brought over from Mexico and Peru found its way to the Ottoman realm, and then some of this silver left to the north and east to pay for Ottoman imports. American silver reached Ottoman shores in the sixteenth century despite Ottoman attitudes and their policy to encourage imports and discourage exports. It was only in the early eighteenth century that some Ottoman intellectuals bemoaned the monies spent on luxuries such as furs from Russia and silk and jewels from Iran and India, whether they had heard of bullionism or not.

On the southern front Ottoman policy was deliberate. In the year 1500 they had been strategic rivals of the Mamluk Sultanate that ruled in Egypt and Syria and therefore controlled the old spice route from the Indian Ocean and the Red Sea to the Syrian and Egyptian ports in the Mediterranean. Within a few years of Vasco da Gama's momentous journey around the Cape of Good Hope into the Indian Ocean Portuguese ships appeared in the Red Sea to threaten this lucrative trade. For the new route to the sources of the spice trade to be economically viable and successful the Portuguese needed to block the old route and not just to operate as a rival. The Mamluks did not have the naval and gunpowder know-how to resist the Portuguese threat, but their misfortune was also a blow to Venice, the primary trading partner of the Mamluk sultans, and even to the Ottomans, their erstwhile rivals, for part of this trade found its way north through Syria to Ottoman markets. Neither of these Mediterranean powers were able to help the Mamluks with ships or gunners. In the event, because of momentous changes in the power alignment in the Muslim world of West Asia as much as the Ottoman understanding of the greater, world-wide strategic implications of the Portuguese threat to the Spice Route, Selim I decided to conquer Mamluk lands for himself. This was accomplished in a long, continuous campaign over 1516-1517 when the Ottoman army, as it marched south through Syria and into the Sinai on its way to Cairo, was supported and supplied by the newly increased navy. Once Syria and Egypt were secured, one of the first acts of the new rulers of the region was to set up a naval command at 
Suez to repel the Portuguese and carry the struggle to the Arabian Sea. ${ }^{11}$ This southward expansion brought significant cash revenues. The tribute of Egypt, the surplus of revenues after local officers and troops were remunerated, went directly into the sultan's treasury. The customs revenues of Yemen, controlling the entrance to the Red Sea, also supplied considerable cash income. ${ }^{12}$ Yet, neither the augmentation of cash revenues for the sultan nor the increased circulation of coin in the realm was sufficient to pay the household troops whose numbers swelled faster than money became available. In 1589 when the janissaries were paid in newly struck, copper-rich, silver coins, worth half of proper, sound coinage, they rebelled and had the sultan's chief financial officer executed. Indeed, most of the following sixty years or so of Ottoman central politics can be read as a struggle between the household cavalry and the janissary infantry over access to additional revenues to augment their nominal wages. ${ }^{13}$

The consequence of these developments for provincial administration was that the traditional arrangements gradually became obsolete. The revenue-grant system was not abandoned until the nineteenth century, and in some cases at least the provincial cavalry continued to attend campaigns, but at times when the sultan's central treasury needed cash infusion they were asked for money rather than service. This was done for the first time around 1650 under the rubric of bedel-ittmar, "revenue-grant substitute", which would have been considered a contradiction in terms half a century earlier. A ttmar was the right to collect revenues, usually at the village level, consisting of peasant rent and tithe given to a cavalryman; by definition it was not itself taxed; a cash substitute was therefore an anomaly. But at the time, when war with Venice was raging over Crete, the need for cash, mostly for the navy, was paramount, and the tımar-holders were not needed on campaign. What had been granted for military service was now taken back in lieu of service. The 'tımar substitute' was not a tax as such, but another way to raise cash revenues for the centre was to turn what had been an extraordinary levy on the subjects, townsmen and peasants, into a routine tax. This was a levy called avârız, exceptional,

11 See, for example, Palmira Brummett, Ottoman Seapower and Levantine Diplomacy in the Age of Discovery (Albany, 1994).

12 See the collections of articles by Salih Özbaran, Ottoman Expansion towards the Indian Ocean in the 16th century (Istanbul, 1994) and Ottoman Response to European Expansion: Studies on Ottoman-Portuguese Relations in the Indian Ocean and Ottoman Administration in the Arab Lands in the 16th century (Istanbul, 1994). Also Giancarlo Casale, The Ottoman Age of Exploration (Oxford, 2010).

13 The best overview of Ottoman money is Şevket Pamuk, A Monetary History of the Ottoman Empire (Cambridge, 2000). 
collected in cash in emergencies. By the early seventeenth century avârız came to be collected annually. For the revenue-grant substitute and for the now routine avârız to be paid in cash agrarian produce had to be marketed, a process made possible by the increased amount of silver and quickened circulation of coin in the realm.

\section{New Methods of Tax Collection}

Peasant rent and the non-Muslim cizye tax, both for (nuclear-)family/households (hâne), were the main traditional collections in cash. The peasant rent per household remained as it was; in the case of cizye and avârzz the term 'household' though still employed, came to have a totally different meaning: instead of denoting a nuclear family it now meant a 'tax-unit' of a specific amount of tax, the size of the unit changeable according to ability to pay. This was a progressive, egalitarian feature of Ottoman taxation and fines. The ground rent for peasants, for example, was the same for all peasant households, but the amount of land each household held varied according to productivity of arable land: a smaller holding for well-watered bottom land, a larger one for middling quality of land, and one still larger for difficult to till stony, infertile land. The ideal was for peasant families to have equal production. A similar three-fold classification, this time of wealth was observed for fines: for the same transgression wealthier subjects were liable for double the amount owed by those of middling income who, in their turn, paid double what the poor owed. This ratio of 4:2:1 was the standard also for cizye payments. Now, in the seventeenth-century re-organisation, this principle of progressive taxation was introduced to the new concept of 'household' (hâne) as taxation unit for cizye and avârız assessment: the number of real—nuclear-households (families) in an avârı 'household' was smaller for richer subjects, greater for those considered middling, and still greater for poorer people, so that the tax burden was lighter on the poor and heavier on the relatively rich. In the new system cizye and avârız tax liability fell on a collective rather than on individual, real households as in the case of peasant ground rent.

The centre decided on the amount of tax to be collected in a given locality; in the provinces communities decided how to apportion the tax burden in consultation with government officials. Of course there was need to consult locals from the very beginning of Ottoman rule. When taxing the agrarian economy was the main business of the government, registers were drawn up for each banner district by means of officials knowledgeable about the district. The first item was a code of regulations (kânûnnâme) for the locality which set what was to be taxed and at what rate as well as listing transgressions and fines to be collected. Ground rent, tithes, market dues, taxation of mills and fisheries, 
in effect whatever was of economic value in the district, were here specified, as well as relations between the peasants and the holder of the revenue grant. ${ }^{14}$ Then peasant households were counted and production was estimated for each household. The result was what was called the detailed census register (mufassal), accompanied by the summary register (icmal) which showed the revenue grants. The officials preparing the district census registers talked to local community leaders about production estimates and about regulations in effect before the Ottoman conquest and harmonised the existing situation with Ottoman principles. ${ }^{15}$

\section{Different Governors for Different Purposes}

Two trends emerged in the new era in terms of provincial administration, linked to one another. One was the erosion of the status of the sancakbeyi banner commanders, until then the backbone of central presence in the realm; the second was the concentration of power in the hands of provincial governors, the beylerbeyi. The loss of status of the banner commanders was a result of their close identification with provincial cavalry; as the need for revenue-grant-holding cavalry on imperial campaigns diminished so did the position of the banner commanders. The second trend, making the provincial governors even more powerful than before was partly a result of the weakening of the sancakbeyi, but also of the deliberate policy of the centre to deal directly with about thirty or so beylerbeyi rather with over 300 sancakbeyi. ${ }^{16}$

The new-style provincial governors had different functions in different situations. In an interior province the governor was to raise cash revenues and transmit them to the centre. Such a governor was now styled a nâzır-ı emvâl, a supervisor of revenues, and placed above the defterdâr provincial treasurer, the traditional agent of the sultan, and all other revenue collectors and tax farmers. Writing in the late sixteenth century the famous historian and political critic Mustafa Âli complained that candidates would not hesitate to pay the treasury 40,000 gold pieces to be appointed a revenue-supervising governor in an important province such as Baghdad when their official allocation was much less, because they knew they could make a lot more for themselves. A governor as supervisor of revenues was responsible for significant amounts of cash, perhaps as much as ten times a governor's traditional allocation; by

\footnotetext{
14 See n. 2, above.

15 In addition to works cited in n. 2, see Colin Imber, 'How Islamic was Ottoman Law?', forthcoming in 2011 ISAM Papers, and "An Illiberal Descent": Kemalism and Ottoman Law', Eurasian Studies IV/2 (2005), 215-243.

16 I have analysed these developments in The Sultan's Servants (New York, 1983).
} 
the second half of the seventeenth century Mustafa Âli's figures do not seem exaggerated but plausible even in a lesser province such as Diyarbekir. ${ }^{17}$ The revenue supervisor collaborated not with the banner commanders of his province but with notables of various localities in this task. He allowed them a share of the revenues they raised, just as he himself was allowed a significant portion, nearly a half, of the cash he transmitted to the centre.

On the frontiers the situation was different. There the governor was styled a muhafiz, a defender or keeper, indicating that his primary function was military. In regions bordering a potentially threatening external enemy the traditional provincial arrangements lasted longer. ${ }^{18}$ There both the revenue-grant cavalry and the banner commanders sustained their accustomed role and supported the beylerbeyi. In such areas revenue-raising too was left to treasurers. Indeed there would be an infusion of funds from the centre rather than the other way round. The reform movement starting with the Köprülü family of grand vezirs in the second half of the seventeenth century aimed at expansion to return to the glory days of Suleiman the Magnificent; this too helped to bolster the military administration in frontier regions to the north. Yet this policy proved unsustainable, certainly in the aftermath of the disastrous siege of Vienna in 1683 . The term beylerbeyi eventually became more a rank than an office; provincial governors were designated by their true functions as revenue collectors or keepers of the frontiers.

\section{Kâdı and Âyân}

In the new situation of the seventeenth century the centre was not interested in the peasant economy as such and left it to be resolved between the revenue holders and the peasants. The disinterest is evident even to the extent that the practice of updating the registers, both the detailed and the summary, at least once every generation, was abandoned. Instead there were now new registers, of avârız and cizye households; at the centre instead of daybooks (rûznamçe) of revenue-grant appointments and dismissals there were now daybooks of cash flow. Secondly, instead of dealing with peasants and townsmen as heads of

17 Metin Kunt, Bir Osmanlı Valisinin Yıllık Gelir-Gideri, Diyarbekir 1670-71 [The Annual Income and Expenditures of an Ottoman Governor, Diyarbekir 1670-71] (Istanbul, 1981).

18 In general, Rhoads Murphey, Ottoman Warfare, 1500-1700 (London, 1999); on frontier fortresses in Hungary, Mark L. Stein, Guarding the Frontier: Ottoman Border Forts and Garrisons in Europe (London, 2007), but it would be better to follow the work of Gabor Agoston, Geza David, and Pal Fodor. 
nuclear families, the centre left the apportioning to communities themselves in a given locality, whether these were denominational or guilds. With the district waning as the main administrative unit along with the district governor the need for official representatives of the government between the level of the provincial governor and the populace came to be filled by the kâdı magistrates. As the actors changed so did the scripts. Instead of the hundreds of census registers of the fifteenth and sixteenth centuries we have thousands of kâdı court records (sicil registers) from $1600 \mathrm{on}$. The change in sources changed the character of Ottoman studies itself. An earlier generation was preoccupied with publishing the detailed census registers and analysing them; in the last three decades social history based on court records has come to dominate the field.

\section{Kâdı as Provincial Magistrate}

Kâdıs were appointed throughout the realm, with a strict career structure: depending on the level of their medrese education their first post would be in a small town, rising through the grades to larger towns and cities. At the top of the profession were the two high magistrates, kâdıaskers, who sat in the imperial council (dîvân), one for each general region of the empire, Rumeli (European territories) and Anatolia (standing for all Asian territories). The two kâdıaskers drew up appointments of kâdıs in their respective regions; Ottoman ulemâ were no less a centrally administered army of state servants than their ümerâ counterparts. ${ }^{19}$ Whether in a small town or in a big city a $k \hat{a} d \iota$ heard cases and adjudicated, but he also acted as a notary, certifying and recording various documents. His court daybook, the sicil register, where all cases and documents were summarised also included any communication from Istanbul. Such orders might be on any state business, from supervising the processes of apportioning and collecting revenues due to the centre to provisioning of troops on campaign or the supply of architectural or ship-building materials. In terms of his function as a judge the kâdı was totally independent, the only higher court being the imperial council itself. Even when plaintiffs

19 The classic study of the ulemâ career is in İsmail Hakkı Uzunçarşılı, Osmanlı Devletinin İlmiye Teşkilâtı, [The Learned Career in the Ottoman State] (Ankara, 1965). Marshall G.H. Hodgson, in his great work on the Islamic world, Venture of Islam, Vol. 3: Gunpowder Empires and Modern Times (Chicago, 1977), discussed the bureaucratisation of the ulemâ in the Ottoman realm as opposed to their relative independence from political authority in other Islamic polities. See also Madeline C. Zilf, The Politics of Piety: Ottoman Ulema in the Post-Classical Age (Minneapolis, 1988). Since then studies on kâdıs, courts and court records have proliferated. 
or defendants in a given case appealed to Istanbul, the procedure would be to ask the kâdı to review the evidence and his decision rather than overturning it.

When the kâdı convened the court he was attended not only by lesser officials like deputies and bailiffs but also by a group of leading townsmen referred to as 'witnesses', şuhûd el-hâl. These were not witnesses to any specific case but rather as expert or character witnesses, knowledgeable about local society and its ways which the kâdı, an outsider who was there only for a year or two might not be aware of. These 'witnesses' testified also to reputations of people involved in various cases. Neither a proper jury nor proper witnesses, the şuhûd el-hâl in effect represented the conscience of the community. ${ }^{20}$ Nor were they the common man; the composition of the group attending the court on any given day might be somewhat different, but they were all members of the town's elite, the respectable people, the âyân. They were neither elected nor appointed, at least not before the eighteenth century, but everybody knew who they were. Because the kâdı listened to them, they could influence court decisions which further enhanced their social standing.

\section{The Rise of the Âyân}

Âyân were simply notables, the leaders of a community. When Evliya Çelebi, the seventeenth-century Ottoman official who travelled throughout the empire during his long career for public business or private purposes, wrote at the end of his life his travelling memoirs in ten huge volumes, he had a standard way of describing a locality he visited: its history, how its people look, how they dress, how they speak, their manners and their food, their delicacies, the various buildings, etc. At the beginning of such a list he entered the âyân notables: officials serving or retired, learned men, and others who are prominent for some reason or another. By 1800 the term had changed meaning completely, to indicate local dynasties, officially recognised and designated, some in effect rulers of vast stretches of land. How this transformation happened, how the âyân in effect displaced at least some of the imperial governors has been the major preoccupation of much current Ottoman historiography. Volume 3 of the recent Cambridge History of Turkey, 1603-1839 has a whole section on the phenomenon in three chapters by three distinguished scholars,

20 The best discussion of the 'witnesses' is in Hülya Canbakal, Society and Politics in an Ottoman Town: 'Ayntab in the 17th Century (Leiden, 2007). Also Boğaç Ergene, Local Court, Provincial Society and Justice in the Ottoman Empire: Legal Practice and Dispute Resolution in Cankiri and Kastamonu (1652-1744) (Leiden, 2003). 
each on a region or aspect. ${ }^{21}$ Here I will focus on the ways in which the provincial notables bolstered their standing so that by the mid-eighteenth century they came to receive diplomas of office as âyân, indicating imperial recognition of their status.

The people Evliya Çelebi noticed as the âyân of a town were probably the same people who sat as community witnesses in the court of 'Ayntab (now Gaziantep). Sitting at court and having the potential to influence its decisions and actions was one of the ways the notable persons of a town reinforced their social standing. Another channel of âyân influence was directly related to the decline of the status of the district banner commander and the fact that some districts were awarded as sinecure to officials with the rank of beylerbeyi without a proper posting. A governor, either a beylerbeyi travelling a long distance from one post to another, or even a sancakbeyi sitting out a period out of office before he achieved a new post, had to make preparations for the road and fit out his official household. This took some time, so the governor sent an agent ahead to his new assignment, to take over from the previous governor. This agent, in effect a deputy or interim governor, was called a mütesellim; he was a senior member of the governor's official household, a majordomo, a chief steward. He had important responsibilities for he inspected the financial and other registers of the province or district turned over by the previous governor and served as acting governor until his master arrived, perhaps weeks or months later. A beylerbeyi assigned a sancak as sinecure might not go there at all but leave his post in the hands of the agent. ${ }^{22}$ It also happened, increasingly more often, that instead of sending his chief steward, the nominal holder of the post might ask one of the local notables to act as his mütesellim; after all a person in situ, who was a native, would be able to take charge faster and with better knowledge of the local situation. By the eighteenth century each district had a few of the most important local families whose members took up this role of interim governor.

21 Edited by Suraiya N. Faroqhi, 2006; Part III: Chapters 7-9, Dina Rizk Khoury, 'The Ottoman centre versus provincial power-holders'; Fikret Adanır, 'Semi-autonomous forces in the Balkans and Anatolia'; Bruce Masters, 'Semi-autonomous forces in the Arab provinces'. The first monograph on the subject providing a basic overview is Yücel Özkaya, Osmanlı Imparatorluğunda Âyânlık [The Institution of Âyân in the Ottoman Empire] (Ankara, 1977). A recent important volume is Antonis Anastasopoulos, ed., Provincial Elites in the Ottoman Empire (Rethymno, 2005).

22 There is now a study of the institution: Fatma Şimşek, Anadolu Sancaklarında Mütesellimlik Kurumu (XVIII. Yüzyll) [The Institution of Mütesellim in Anatolian Districts in the 18th c.] (Antalya, 2010). 
Up to the 168 os provincial notables may have been content to wield their influence assisting at the $k \hat{a} d \iota$ court and occasionally serving as agents of a governor, but the long war that started after the siege of Vienna in 1683 changed the status quo. Once again war conditions forced $a d$ hoc arrangements in Ottoman polity. The defeat and retreat from Vienna in 1683 started a war that lasted sixteen years until the Treaty of Karlowitz ended it in 1699. The Ottomans fought not only against the Austrians but also faced Poland, Russia, and Venice. As the war was prolonged, regular Ottoman armies had difficulty sustaining almost continuous campaigns. To be able to field troops year after year the centre decided to ask for contributions from the âyân. The more prominent among them were requested to supply, at their own expense, a number of men, fifty or one hundred or more, depending on the perceived means of the individual âyân. ${ }^{23}$ The âyân obliged, the centre was obligated. Istanbul asked the provincial notables in effect to become more involved in military matters, to have their own men-at-arms, much like the official households of governors. The men recruited were mercenaries, bands of men gathered around captains, known collectively and quaintly as levend, well-built tough rogues, though originally the term referred to sailors. ${ }^{24}$ Governors too made use of these mercenaries; it was cheaper contracting them seasonally rather than keeping their own troops the year round. ${ }^{25}$ Even the centre had hired mercenaries on occasion since the end of the sixteenth century, but these were sekbân in larger groups, better trained and better disciplined. However, the long war of 1683-99 was the first time that provincial notables established ties with levend mercenaries, ties that were maintained into the eighteenth century.

Another feature of ad hoc reforms during the war years was the fiscal institution of mâlikâne, life-time tax-farms. ${ }^{26}$ These were instituted primarily to raise funds quickly to meet war expenditures, but there was also a longer-term purpose. Being aware that short-term tax-farmers tended to recoup their purchase price and maximise profits in a year or two, the hope was that a long-term, indeed life-time tax-farmer would have an interest in the productive potential of their revenue source and the prosperity of their peasants. The original meaning of the term mâlikâne is 'as if owned'; there could be no real ownership

\footnotetext{
23 The ground-breaking article by Halil İnalcık, 'Military and Fiscal Transformation in the Ottoman Empire, 1600-1700', Archivum Ottomanicum 6 (1980), 283-337.

24 Mustafa Cezar, Osmanlı Tarihinde Levendler [Levends in Ottoman History] (Istanbul, 1965) provides a detailed study of the phenomenon.

25 Cf. n. 17.

26 The classic study of the institution is by Mehmet Genç, Osmanlı Maliyesinde Mâlikâne Sistemi [The Mâlikâne System in Ottoman Fiscal Administration] (Ankara, 1975).
} 
of land 'owned' by the sultan in the name of the transcendental 'state', but it is interesting to note that in modern Turkish it has come to mean an estate, or more specifically a mansion. The 'purchaser' of the life-time tax-farm put up a substantial amount initially and then paid the central treasury a yearly due. People who had the capital to be able to pay the initial purchase price tended to be members of the imperial family and grandees in Istanbul. ${ }^{27}$ Even if there were rich enough merchants and financiers outside the political elite, they tended to do business through partners in palace or government service. ${ }^{28}$ The result was that in many cases the Istanbul personages who bought the life-time tax-farms then sub-contracted them out to people on the spot, the âyân. The initial short-term receipts to the treasury were thus followed in the longer term by a flow of capital accumulation from the provinces to the centre. On the other hand, it allowed the power of the provincial notables in their localities to grow even stronger.

In the course of the eighteenth century local powerholders proliferated and came in different types and different sizes. In the literature there is sometimes an unfortunate tendency to group them all together under the rubric of âyân, but this practice unnecessarily obscures the divergent varieties. The more traditional, relatively small-scale provincial notables continued to exert influence in their towns and in the countryside through the mechanisms outlined above. They cooperated with the centre either directly through their tax-collecting activities or indirectly through their cooperation with representatives of the centre, chief among them the $k \hat{a} d \iota$ magistrates. Their growing importance was acknowledged first by granting them the honorary but nevertheless significant and coveted title of 'palace gatekeepers' (kapucubaşı). Such âyân sometimes dominated local politics to the extent of mobilising the townsmen to protest the appointment of a certain governor, in effect declaring the centre's nominee to be persona non grata. By and large, however, they were loyal to the central government. In addition to such âyân there were also janissaries serving in some provincial centres of economic importance, such as Belgrade and Aleppo, where they dominated the marketplace and ran the cities. ${ }^{29}$

27 See another classic article by Halil İnalcık, 'Capital Formation in the Ottoman Empire', Journal of Economic History 29 no. 1 (1969), 97-140.

28 Linda Darling, Revenue-Raising and Legitimacy: Tax Collection and Finance Administration in the Ottoman Empire, 1560-1660 (Leiden, 1996). See also her contribution to the Cambridge History of Turkey, Vol 3, 'Public Finances: the Role of the Ottoman Centre'.

29 See the various articles in Antonis Anastasopoulos and Elias Kolovos, eds., Ottoman Rule and the Balkans, 1760-1850 (Rethymno, 2007) and Antonis Anastasopoulos, ed., Political Initiatives 'From the Bottom Up' in the Ottoman Empire (Crete, 2012). 
Ottoman decentralisation reached a crisis point by the early nineteenth century only in part because of the activities of the first two groups. Far more dangerous for the integrity of the empire was a third group of provinces, more distant from the centre, with direct access to the outside world especially in the Mediterranean and therefore able to develop their own cash-crop agrarian systems for the export trade. North African provinces of Algiers, Tunis, and Tripoli had already in the seventeenth century been allowed to drift apart to establish their own political, economic, and even diplomatic arrangements in return for naval reinforcements to the centre especially during the long war with Venice in the process of the conquest of Crete (1645-1669). There the local military elected their own leaders and constituted a non-dynastic rule by captains. In the first half of the eighteenth century Baghdad and Damascus joined such provinces though through different routes. In Damascus the local family of al-Azm kept the governorships in various provinces of greater Syria for a considerable period. ${ }^{30} \mathrm{~A}$ different kind of 'family', at first dynastic but continued through their military household, took over and held power in Baghdad and Basra from the early eighteenth century for more than a hundred years. ${ }^{31}$ In the second half of the eighteenth century Palestine became the domain of Cezzar Ahmet Pasha, originally an Ottoman official..$^{32}$ At about the same time in Egypt local military households which had continued to flourish under Ottoman rule took over completely. ${ }^{33}$ Perhaps the most famous of such regional rulers, at least in the European imagination because of his Lord Byron connection, is Ali Pasha of Yannina. ${ }^{34}$

These examples went far beyond the petty âyân of yesteryear. From Greece, northern Bulgaria, Syria, Palestine, Baghdad, and finally to Egypt the provinces behaved independently from the centre both politically and economically. They established their own economic ties to outside powers and conducted their own diplomacy. Even in relatively quiet Anatolia some âyân controlled extensive lands. It is perhaps a charitable view to say that by 1800 the Ottoman Empire had become a commonwealth, a loose confederation of regional rulers throughout the realm who paid lip service to the sultan-caliph in Istanbul

$30 \quad$ Karl K. Barbir, Ottoman Rule in Damascus, 1708-1758 (Princeton, 1980).

31 S.H. Longrigg, Four Centuries of Modern Iraq (Oxford, 1925), reprinted.

32 Amnon Cohen, Palestine in the 18th Century (Jerusalem, 1973).

33 Jane Hathaway, The Politics of Households in Ottoman Egypt (Cambridge, UK, 1997) and M.W. Daly, ed., The Cambridge History of Egypt, Vol. 2: Modern Egypt From 1517 (Cambridge, 1998).

34 Katherine Elizabeth Fleming, The Muslim Bonaparte: Diplomacy and Orientalism in Ali Pasha's Greece (Princeton, 1999). 
and sometimes even cash tribute. This commonwealth might have established a modus vivendi and continued in its peculiar way, but it did not exist on its own. The various sections of the commonwealth as well as the centre itself were under increasing European pressure; the loose Ottoman network would have disintegrated under such external strain. That is why the first priority of the centre around 1800 was to reform its military capacity and even its politics in the European manner. The new-style army was used first against Napoleon in Palestine and Egypt, and then was directed against the more rebellious regional rulers. Facing external defeat at the hands of Russia, even the âyân conceded the need for military reform, in the realisation that they themselves could exist only within an Ottoman commonwealth. They therefore committed themselves to the unity of the realm in the 1808 'Deed of Alliance', Sened- $i$ Itttifak, recognising the sultan as supreme. The greatest regional ruler of them all, Mehmed Ali Pasha of Egypt, even when he waged war on the centre in the 183 os claimed he did so to save the sultan and his state, not to depose him. It is significant that many Ottoman grandees of the centre believed him.

Finally we should note the two ironies of this story of extreme devolution. One is, that the Ottoman programme of centralisation at the turn of the seventeenth century carried the seeds of the rise of provincial power holders. The centre came to depend on them, and they took from the centre functions appropriate for their new role. The second irony came at the end of the process. In the second half of the eighteenth century it was the world outside Ottoman domains that encouraged and facilitated Ottoman decentralisation, through trade or political and military intervention, in the shape of France in the Mediterranean and Austria and Russia in the Danubian basin. Yet it was Britain, another outside actor, and the other Great Powers that stopped Mehmed Ali Pasha in the 1830 and shored up the Ottoman centre. The worldwide changes that had started in the sixteenth century had helped the Ottoman sultans in their political ambitions. By the nineteenth century these changes had reached such a pitch that the sultans were no longer independent actors even in the internal affairs of their realm. 